\title{
INTERNATIONAL LAW AND GLOBAL POLITICS IN A POST-PANDEMIC WORLD: HOMO SAPIENS?
}

\author{
Mario Patrono*
}

\begin{abstract}
This article discusses the Coronavirus pandemic: A deep wound destined, sooner or later, to heal, or instead sow the seed of a global revolution? The first part examines the history of war and peace among nations to propose the idea of an International Court of Justice endowed with compulsory jurisdiction as the first step towards the creation of a world State. The second part further considers a changed New Global Order in the face of crises.
\end{abstract}

Melting before our eyes like snow under the sun is the paradigm of the civilisation that has shaped us over the last two hundred years: that we are the masters of Creation, that we can do everything, and that the world belongs to us. New times are coming!

Olga Tokarczuk, Nobel Prize winner for Literature 2018, Frankfurter Allgemeine Zeitung (4 April 2020).

Nobody on board the vessel on which we human beings live can ignore the big icebergs ahead on our route: we have to steer clear of them at all costs, otherwise we run the risk of sinking after the collision.

Amin Maalouf, Member of the Académie française (21 May 2020).

I THE CORONAVIRUS PANDEMIC: A DEEP WOUND

DESTINED, SOONER OR LATER, TO HEAL, OR INSTEAD

THE SEED OF A GLOBAL REVOLUTION? SOME

REFLECTIONS BY WAY OF INTRODUCTION

The damage Covid-19 has caused in its vertiginous passage through every nation has proved devastating, in terms of human lives, but also in financial, economic and social terms. "Like after a war", it has been said and written, more than once. An anomalous war, certainly; a war against an

* Emeritus Professor of European and Comparative Public Law at "La Sapienza" University of Rome; former director of the Department of Legal Studies at the University of Padua, and member of Higher Council for Judiciary (Consiglio Superiore della Magistratura); and several times visiting professor of the Law Faculty of Victoria University of Wellington | Te Herenga Waka. 
invisible enemy - aggressive, unknown, deadly. ${ }^{1}$ The long parade of army lorries transporting the coffins of Covid-19 victims from Bergamo (in the region of Lombardy, North Italy), where the cemetery was already full, to other cities for burial, symbolises the image of this "war".

"Like after a war" is the first, prevalent impression left by the pandemic. Another one is that "after 2020, nothing will ever be like it was before". As Nicolas Hulot, former French Minister for Ecological and Inclusive Transition stated, "The world afterwards will be radically different from that of today, and it will be so by will or by force". ${ }^{2}$ Similarly, but perhaps in a less peremptory manner, Ece Temelkuran wrote in the early days of the pandemic: "If and when the day will come when this is all over, that day will probably not be the return to 'normality'. It seems that normality we will have will be a brand new normality". 3

There is a connection between these statements. Plagues - the word being used in a generic sense - drive change. In the aftermath of the pandemic, great changes will occur, not least in the sphere of social life. Ilaria Capua, Director of One Health Center of the University of Florida, ${ }^{4}$ lists the many challenges issued by Covid-19: "It is a stress-test for family economies, for the health service and for the future way of performing many jobs. It will also give rise to new models for the organisation of schools and universities. It will affect religion, sport, entertainment, international tourism, and will bring to the surface fragile systems, such as that of conurbations".

Prominent emergencies and disasters, however, can also lead to spurts of planning, both institutional and economic, even to quantum leaps in the way political communities stick together and organise social cooperation, both within and among States. After the Great Depression of the 1930s, President Roosevelt launched the New Deal. From the wreckage of World War II (WWII) emerged the modern Welfare State, and it was this context that gave shape to the emerging age of international organisations, especially the United Nations (UN) and later the European Union (EU).

Similarly, a turning point could now come about due to the Covid-19 pandemic and the ensuing economic and social devastation, along with the possible alteration of inter-State relations in its aftermath. As Yuval Noah Harari, the prestigious author of Sapiens, Homo Deus, and 21 Lessons for the 21st Century, wrote, every crisis is also an opportunity". He goes on to say: "We must hope that

1 Queen Elizabeth II herself compared war and Covid-19 in her speech marking the 75th anniversary of VE Day, May 8, 2020, in which she underlined the analogy between the fortitude displayed by the British people in the course of World War II and that showed again by her people as the pandemic raged over Britain: Queen Elizabeth II "An address by Her Majesty the Queen on the 75th anniversary of VE Day" (8 May 2020).

2 Le Monde Diplomatique (France, 6 May 2020).

3 Internazionale (Rome, Italy, 3 April 2020) at 42; and DuvaR.english (online ed, Turkey) <www.duvarenglish.com>.

4 Corriere della Sera (Milan, Italy, 13 May 2020). 
the current epidemic will help humankind realise the acute danger posed by global disunity". 5 Harari's statement is on point. In the light of recent global problems, a great window of opportunity has opened to allow us to reflect on the kind of society and overall organisation of the world we want. It is evident today that we are living in a troubled world, of which we are not (as we perhaps were convinced we were) undisputed masters, a world which, on the contrary, could suddenly attack and overwhelm humankind. ${ }^{6}$ The world in which we live is under serious strain, gravely ailing due to conflicts between nations, but also relentless pressure on Nature. ${ }^{7}$ Our Planet is ever more suffering and inhospitable. A Planet blood-soaked by a myriad of local conflicts that, at any moment, could degenerate into wider conflicts.

The drama of Covid-19, the latest of a series of pandemics flaring at (ever shorter) intervals in the first two decades of this Millennium, rings as a warning to humankind's Reason: without peace among nations, and respect for Nature, the human race faces the greatest existential risk of its history. If human Reason does not treat this pandemic, as it has too often done with other threats, as a transitory, fleeting contingency, the 2020 pandemic may instead serve as the starting point for a New Beginning.

Now, this affirmation - the 2020 pandemic as a New Beginning - can be said to be the arrival point, an objective to be achieved more than a starting point. In fact, the starting point is that on the field today, playing their future, are three competing forces. One is pressing to wind back the clock of history: nationalism, customs barriers, authoritarian state rule, primacy of the executive branch over individual rights and the institutions restraining power and breakup of the great international organisations born at the end of WWII. The second wants to carry on in the same way as usual: no need to change, the world is progressing in the right direction. The third, too, wants to move ahead, but along a different road: it accepts the need for change, understanding that the world heads in the wrong direction.

In this contribution to this special issue celebrating the career of my esteemed friend and

5 Yuval Noah Harari "Yuval Noah Harari: the world after coronavirus" Financial Times (online ed, London, 20 March 2020) <www.ft.com>.

6 As articulated by Pope Franics, pronouncing his Urbiu et Orbi speech from the Sagrato of St Peter's Basilica in Rome to a rain-swept empty square:

We have not been reawakened by wars and injustice across the world, we have not heeded the cry of the poor, nor that of our ailing planet. We have carried on heedlessly, thinking that we alone could stay healthy in an unhealthy world.

See Pope Francis "'Urbi et Orbi'" Message of His Holiness Pope Francis" (Benediction Hall, Rome, 20 April 2020).

7 Even as the world is going through a wide lockdown, the Secretary-General of the United Nations, António Guterres, was imploring in vain that battle forces in the various war zones "end the sickness of war and fight the disease that is ravaging our world": see António Guterres "The Fury of the Virus illustrates the folly of war" United Nations <www.un.org>. 
colleague, John Prebble, I aim to show that neither the first nor the second approach are consistent with the goal - now imperative - of safeguarding humankind. To protect our future, peace is essential if we indeed want all nations to strive jointly and separately to devise a virtuous and civil co-existence with the Planet, and among ourselves on the Planet.

Peace among nations cannot but precede the common endeavour to save the Planet and with it humankind. It is based on the idea that nations know how to take preventative action and are able to adopt forward-looking measures where necessary. Building peace among nations, then, is the first and most urgent task today, hinging on the attention of the world's governments, the same task that awaited the delegates assigned to the San Francisco Conference in 1945. This pivotal event, aimed at drafting the Charter of the UN, generated, at the time, all kinds of ideas and power structures, some realised and still operational, others abandoned, but all destined to serve peace. The San Francisco Conference led to the creation of what was soon to become the "New World Order". It is possible to continue to build on its foundations to achieve a more widespread and steadier peace among nations, but in order to do so, it is important to reassess them with a view to addressing the needs of a future that is no longer so distant.

\section{PART ONE: PEACE AMONG NATIONS, A NECESSARY STEP TOWARDS PEACE BETWEEN NATIONS AND NATURE. PROBING THE PAST IN SEARCH OF THE FUTURE}

Let us turn, first, to an overview of the politics and law that produced the New World Order. The aim of the first part of the article is to point out its structural foundations and underline some of its ongoing issues. We also hope to highlight the protagonists who, with their ideas, contributed to its realisation, and to mention those who foretold the distant future, despite being ignored at the time. No doubt, the situation today certainly differs from that prevailing in the mid-1940s, but the spirit is the same; and it is from that crucible of organising ideas and structures that we must set off again, towards the world of the future.

\section{A For Peace in the Post-WWII World, a New Problem Dawns: How to Pry the Claws of War from the Sovereignty of States. Two alternatives Solutions.}

The date of 2 September 1945 marks the end of WWII, with the surrender of the Japanese Empire. On that momentous day, the entire human race proclaimed loud and clear its irrevocable veto: "no more war!", 8 echoing the words of Immanuel Kant about 150 years before: "There should be no war". 9

8 A decision that Queen Elizabeth II explains with simple, wise words: "The wartime generation knew that the best way to honour those who did not come back from the war was to ensure that it didn't happen again". Queen Elizabeth II, above n 1.

9 Immanuel Kant Die Metaphysik der Sitten (Königsberg, Germany, 1979). The first part was published in Königsberg in 1797, concerning the Metaphisische Anfangsgrönde der Rechtslehre. 
Obviously, to eliminate the word "war" from the vocabulary of States, it is not sufficient simply to delete it, as in fact happened with the adoption of the UN Charter. Its 111 articles use the most diverse euphemistic formulations to cover the semantic area traditionally subsumed under the rubric of "war". Hence, the Charter talks of "armed force"10 that should not be used; it refers to "acts of aggression"11 by one State against another that will be abolished; and it requires its member States to pledge to renounce "use of force" 12 except in self-defence. The Charter further speaks of "international enforcement action", 13 "application of armed force" 14 and the need for the UN to make use of the deployment of air, sea, or land forces as means of the last resort "to maintain or restore international peace and security". ${ }^{15}$ The word "war" is thus repealed, indirectly kept alive through the concept of self-defence and that of collective security. In fact, only once is the word "war" murmured in the Charter, in the preamble: "We the peoples of the United Nations determined to save succeeding generations from the scourge of war, which twice in our lifetime has brought untold sorrow to mankind". 16

Far more than a play on words, the effort to ban war as a means of resolving international disputes, proclaimed and repeated by all the leaders of the great Powers, by the greatest intellectuals of the time and the shrewdest jurists, required, in order not to remain an ineffectual proclamation, appropriate instruments in order to build a lasting peace. In practical terms, that meant devising a project to engineer international institutions aimed at the prevention of war, or at least, curbing the use of force where unlawful conduct had occurred.

However, how to do it was the problem. In this regard, for a brief period, two alternative and competing solutions emerged. One vied for a solution through the creation of a (federal) world State. The other, which prevailed, did not espouse such a prospect.

\section{$B$ The Idea of an International Court of Justice Endowed with Compulsory Jurisdiction, as the First Step Towards the Creation of a World State}

Hans Kelsen, the illustrious author of the Reine Rechtslehre (translated as Pure Theory of Law), the scholar of law whom Roscoe Pound - then Dean of the Harvard Law School - defined in 1934 as

10 Charter of the United Nations, preamble and arts 41 and 46.
11 Article 1.
12 Article 2 .
13 Article 45.
14 Article 46.
15 Article 39.
16 Preamble. 
"unquestionably the leading jurist of the time", ${ }^{17}$ had a clear solution to the problem. He expounded it before the end of WWII in Peace through Law, one of the most prolific politological texts of the 20th century. ${ }^{18}$ It consists of a solution that the "pacifist" Kelsen drew from the similarly pacifist thinking of Kant, and pertained to a vast movement of opinion that was taking shape immediately before and after WWII, especially in the United States of America, and that favoured the creation of a federal-type world State. In fact, a blueprint of such a treaty or constitution does exist. ${ }^{19}$

However, Kelsen cautioned, the idea of a universal federal State, albeit not at all abstract, in fact needed to follow a long and slow course before it could be realised. "If one accepts", Kelsen explained, "a World State as a desirable aim, it is more than likely that it can be reached only by a sequence of stages". The first of which should be, Kelsen maintained, "to bring about an international treaty concluded by as many States as possible, victors as well as vanquished, establishing an international court endowed with compulsory jurisdiction". ${ }^{20}$

Kelsen's proposal seemed hardly realistic at the time. Joseph Kunz, one of Kelsen's favourite pupils, could not but define it as "too optimistic". ${ }^{21}$ In effect, the ideas underlying the pacifist thinking

17 Roscoe Pound "Law and the Science of Law in Recent Theories" (1934) 43 Yale L J 525 at 532.

18 Hans Kelsen Peace through Law (University of North Carolina Press, Chapel Hill, 1944).

19 The text of which can be found in the Supplements and Documents of the "American Journal of International Law" of 1944.

20 Kelsen Peace through Law, above n 18, at 14. The solution conceived by Kelsen for the effective reform of international relations - setting up a Court with compulsory jurisdiction - may seem nothing more than the reiteration of the concept that had developed in the inter-war period owing above all to Hersch Lauterpacht, to endow the International Court of Justice with a compulsory character. However, there are differences between the two. For Kelsen, international law - that is, law above the community of states, completely decentralised and dictated by the principle of self-defence - would develop in the same way as primitive law had done in human societies, that is, through a continuous process of centralisation. "This process", reasoned Kelsen:

is characterized by the surprising fact that the centralization of the law - applying function - that is, the establishment of courts - precedes the centralisation of the law-applying function [the establishment of legislative organs.] ... Long before special legislative organs came into existence, courts are established to apply the law to concrete cases ...

[If this is true,] we can with a certain degree of probability foresee the direction in which a relatively successful attempt may be undertaken to secure international peace, to eliminate the principle of selfhelp from international law by emphasizing and strengthening the given tendency toward centralisation. Natural evolution tends first toward international judiciary, and not toward international government or legislation.

Hans Kelsen "Essential Conditions of International Justice" (1941) 35 American Society of International Law at its Annual Meeting 70 at 74.

21 J I Kunz "Compulsory International Adjudication and Maintenance of Peace" (1944) 38 American Journal of Int Law 673. 
of Kelsen as the advocate of a judicial cosmopolitanism based on the binding nature of international law, the primacy of international law over domestic law, and the challenge to the dogma of State sovereignty, were (or seemed to be) light-years away from realisation. So, in the best-case scenario, the idea of ensuring peace by means of law was regarded as a grandiose Utopia. ${ }^{22}$

The fact is that the idea of a transposition of politics into law as regards disputes between States, relying on the conciliatory function of jurisdiction, was of limited relevance within the framework of the endeavours undertaken in the immediate aftermath of WWII aimed at a general pacification of international relations. In fact, as part of the UN, the ICJ was set up to take over the role of the Permanent Court of International Justice. Various proposals were made to render its jurisdiction compulsory, at least with regard to certain issues. However, these proposals were not approved.

Consequently, the ICJ only has jurisdiction over disputes that States submit to it, of their own accord. Consider art 36(2) of the ICJ Statute, which lays down that States adhering to the Statute "may at any time declare that they recognize as compulsory ipso facto and without special agreement, in relation to any other state accepting the same obligation, the jurisdiction of the Court".

\section{The San Francisco Conference Strategy: One Aim, Three Instruments}

For Kelsen, a court endowed with compulsory jurisdiction was essential, but History had other plans. The dream of building a world State based on a constitutional blueprint towards the gradual federalisation of the planet was in fact destined to collide with the harsh reality of a bipolar world. The sudden outbreak of the Cold War between the world's two superpowers of the time, the United States and the Soviet Union, hampered such a noble plan.

For the foundation of peace, the community of States took another path. It proposed building a peaceful framework of international relations consisting in a coordinated, concurrent action strategy with various options.

First of all, the focus was to draw up, by means of a close-knit mesh of norms, mechanisms and procedures, a collective security system. The UN was structured to ensure greater robustness compared to, and address the failures of, the now-defunct League of Nations. The major undertaking pursued during that period by the national decision-makers, political actors and pioneers of a postnational democratic order was to eliminate the causes of war. To do so, it was necessary to identify them, as well as to determine the conditions that could foster a lasting peace. From an intellectual

22 Charles Leben "Hans Kelsen and the Advancement of International Law" (1998) 9 EJIL 287 at 291; Danilo Zolo "Hans Kelsen: International Peace through International Law" (1998) 9 EJIL 306. For a detailed overview of comments made on the publication of Peace through Law, see Judith von Schmadel "Kelsen's Peace through Law and its Reception by his Contemporaries" (2011) 39 Hitotsubashi Journal of Law and Politics 71. Despite the fact that Kelsen's proposal has failed to materialise does not mean that Peace through Law should be deemed a work without practical relevance. On the contrary, it is the fountainhead of radical changes, from different points of view, of the present situation of the international legal system, an examination of which is not within the remit of this article. 
perspective, the answers came inter alia from the works of two great European thinkers of the 18th century, Immanuel Kant and Adam Smith. In particular, Kant contended that the respect of human rights within States promotes peace whereas its disregard leads to war; Smith argued that free trade is the most advanced condition of relations among peoples and the premise of a world order without war. Hence, on the basis of the history of past ideas, the Universal Declaration of Human Rights (UDHR) was adopted by the UN General Assembly on 10 December 1948. ${ }^{23}$ Around the same time arose from the development of economic and financial markets the General Agreement on Tariffs and Trade (GATT) (which then became the World Trade Organization (WTO)), the International Monetary Fund (IMF) and the World Bank. Underpinning the GATT and its supporting institutions was the idea that the development of world markets, stimulating the development of productivity, would favour, alongside the well-being of individuals, peace among peoples, the precondition of economic growth.

\section{$D$ The UN as the Sole Holder of the Legitimate Use of Force in the Absence of a World State, and the Transformation of Jus Belli into Jus Contra Bellum}

The first and certainly the most ambitious, if not the most important, of the ventures undertaken by the major victorious Powers to foster and establish peace in the world was to set up a truly global institution, the Organisation of the United Nations.

In the UN system, the legal prohibition of the use of force, except in cases of self-defence and action authorised by the Security Council, represents an affirmation of the principle that the use of force as sanction should be the legitimate monopoly of the international community. The jus belli of "classical" international law was thus transformed into jus contra bellum. On this essential point, concerning the way to quell "every act of aggression" or other "breach of the peace", the victorious nations departed decisively from the logic that underpinned the Covenant of the League of Nations. The Covenant, which controlled, without much success, international relations after World War I, ${ }^{24}$ set out a short-sighted system of collective security that in fact limited itself to the regulation of war.

The UN Charter went much further. The use of military force, traditionally a prerogative ascribed to the sovereignty of States, no longer pertains as a rule after 1945. In particular, the decision by a

23 Universal Declaration of Human Rights GA Res 217A, A/Res/3/217A (1948).

24 For a convincingly argued critique of the League of Nations, see Hans Kelsen Legal Technique in International Law. A textual Critique of the League Covenant (Columbia University Press and Geneva Research Centre, Geneva, 1939). See also the review by H W Briggs: Herbert W Briggs "Legal Technique in International Law. A Textual Critique of the League Covenant" (1940) 34 AJIL 758. For the more recent literature on the subject, see Stephen Wertheim "The League of Nations: a retreat from international law?" (2017) 7 Journal of Global History 210; Susan Pedersen "Back to the League of Nations" (2007) 112 American Historical Review 1091; and Christian J Tams League of Nations (Oxford Public International Law, Oxford, 2006). 
State to wage war in order to conquer a territory, interfere in the affairs of another State, impose its products or find a better channel for procuring raw materials or to exploit weak or less-developed markets - in a word, the entire range of the traditional goals of war - was deemed unlawful. The only legal use of the recourse to arms was that authorised by the international community under the auspices of the Security Council. Thus, speaks Chapter VII of the UN Charter. ${ }^{25}$ The "removal" of the use of armed force from the basic options at the disposal of the State was the most direct and immediate answer provided by the international community to the problem of war.

\section{E Regional Organisations Supporting the UN: the European Union}

In the immediate post-WWII period, in the same spirit that animated the creation of the UN, arose at the regional level an international organisation of great importance: the European Union (EU). The EU has been named as such since 2009, but originally consisted of the European Coal and Steel Community (ECSC) created in Paris in 1951, and the European Economic Community (EEC) adopted in Rome in 1957. The primary objective of the early European treaties was to work towards consolidating peace in Europe. The preamble of the founding treaty of the ECSC solemnly proclaims the intention of the signatory governments that they: ${ }^{26}$

... resolved to substitute for age-old rivalries the merging of their essential interests; to create, by establishing an economic community, the basis for a broader and deeper community among peoples long divided by bloody conflicts; and to lay the foundations for institutions which will give direction to a destiny henceforward shared.

To that end, the European treaties create a legal framework binding their member States, conditioning their actions, directing their behaviour, "limiting" their domestic sovereignty and - to a certain degree - also their international sovereignty. ${ }^{27}$ It would be no exaggeration to say that nearly all that pertains to the collective life of the population of the member States is subject to some influence of the EU. The EU, in other words, proclaim as a foundational goal "the reduction of the power and centrality of the nation State, in order to institute European solidarity and thereby promote peace in Europe". ${ }^{28}$ The European treaties have set at the centre of their integration strategy a Court of Justice competent to pronounce judgments that are legally binding on member States. The existence of the Court of Justice as the judicial organ of the EU has diverted disputes between member States from the divisive nature of politics towards the certainty of the rule of law, intended as an instrument

25 United Nations Charter, Chapter VII.

26 Treaty Establishing the European Coal and Steel Community 1757 UNTS 107 (signed 18 April 1951, entered into force 23 July 1952), preamble.

27 This applies in particular to those States that, having adhered to the Economic and Monetary Union (EMU), agreed to forsake their national currency and all authority regarding monetary policy, as well as to incur heavy limitations in the field of fiscal policy.

28 Agnes Heller Paradox of the European Nation State and the Stranger (2015) at 8. 
of peace-building. Thus, litigation between States in the EU is resolved not by the use of force, but by the force of the judgments of the Court of Justice. ${ }^{29}$

\section{F Paris 1948, a New Instrument for Peace: Human Rights as Universal Values and a Duty for States}

According to the preamble to the Charter, there are two essential goals that UN states aim to achieve. The first, as we have seen, is to "maintain international peace and security" in order to "save succeeding generations from the scourge of war". The second is to "reaffirm faith in fundamental human rights, in the dignity and worth of the human person, in the equal rights of men and women and of nations large and small". The UDHR, adopted by the UN General Assembly in Paris on 10 December $1948,{ }^{30}$ reflects this second goal. The Declaration, albeit without binding force, constitutes for UN member States a source of principles, an interpretative benchmark and a regulatory framework. It was the first of the three components of the UN Bill of Rights.

Less than two decades later, in 1966, a decisive step was taken with the adoption of two binding instruments, one on civil and political rights, the other on economic, social and cultural rights, introducing a list of universal human rights, both of which entered into force in $1976 .{ }^{31}$

Since then, specialised human rights instruments as well as regional conventions for the protection of human rights have emerged, although there have been differences in the mechanisms contained therein to ensure State compliance with their international obligations. In that regard, the mechanisms for enforcement of the rights listed in the various instruments can be divided, roughly, into two categories. In some conventions, bodies are created to entertain petitions by individuals and State

29 It is interesting to note, in this respect that in its reasons to award the Nobel Peace Prize 2012 to the European Union, the committee acknowledged that the European Union had "for over six decades contributed to the advancement of peace and reconciliation, democracy and human rights in Europe" and the whole world: The Nobel Prize "Nobel Prize awarded organizations" (9 November 2021) <www.nobelprize.org>.

30 Universal Declaration of Human Rights, above n 23.

31 These two Covenants contain, compared to the Declaration, certain new features of the greatest importance. Two in particular. One is the right of all peoples to self-determination; the second is their right to full and free use of their natural resources: International Covenant on Civil and Political Rights GARes 2200, XXI (1966) [ICCPR], art 1.1; and International Covenant on Economic, Social and Cultural Rights GARes 2200A, XXI (1966) [ICESCR], arts 1.1 and 2. With reference to the first of these two "rights", it is worth mentioning that already before the two Covenants of 1966, the UN Charter mentioned the "self-determination of peoples", but in the more generic terms of a "principle": "to develop friendly relations among nations based on respect for the principle of self-determination of peoples" (Charter of the United Nations, arts 1.2, 55 and 56). In Case Concerning East Timor (Portugal v Australia) (Judgment) [1995] ICJ Rep 90, the ICJ, albeit hesitant to recognise the right of peoples to self-determination as a right erga omnes, has nevertheless established that the right in question is "one of the essential principles of contemporary international law": at [29]. On this concept and on the sundry problematic aspects of the "right" in question, see Francisco Martinez Cruz "The Right to Self-determination of Peoples: Notes on its Compatibility with three Models of Global Order" (2018) 11 Mexican Law Review 85. 
parties. Such procedures, normally not binding, result in suggestions, views or recommendations, thus reducing compliance to a means of political pressure. Others, too few, allow individual redress before a human rights court, and, in a way, allow the voice of the victims of violations of human rights to prevail over the sovereignty of the State. At the level of state responsibility, disputes over the interpretation and application of human rights may reach eventually the International Court of Justice, authorised by the convention to hear cases and hold the defaulting State in breach of its human rights obligations. $^{32}$

The first body to recognise that a court of justice "external" to the contracting States could assess the conduct of States in relation to human rights was the European Convention on Human Rights (ECHR) for the protection of human rights and of fundamental freedoms, signed in Rome on 4 November $1950,{ }^{33}$ which acknowledges in its preamble, as do most instruments, the UDHR. The human rights contained in the ECHR fall under the jurisdiction of the European Court of Human Rights (ECtHR), which is invested with judicial powers to hear cases about potential violations of human rights, at the instigation of individuals who find themselves within the jurisdiction of a State party.

The ECHR thus established a precedent that has given birth to a number of regional institutions designed for the protection of human rights, frequently organised on the basis of a mechanism of judicial control, however endowed - compared to the Strasbourg Court - with a lesser degree of force. The American convention on human Rights, with the Inter-American Court of Human Rights, adopted in 1969, and the African Charter of Human and Peoples' Rights adopted at Banjul on 27 June 1981, are two such examples. ${ }^{34}$

To these "general" human rights instruments aiming to strengthen the subordination of the conduct of States and of their agents to judicial control, it is important to add the development of international criminal law after the end of the Cold War. Such a movement started with the creation by the UN Security Council of two ad hoc international criminal tribunals set up to prosecute those most

32 See discussion of these procedures in Paul Comrie-Thomson and Scott Davidson "Human Rights" in Alberto Costi (ed) Public International Law: A New Zealand Perspective (LexisNexis NZ Limited, Wellington, 2020) 633 at $653-661$.

33 European Convention on Human Rights 213 UNTS 223 (signed 4 November 1950, entered into force 3 September 1953).

34 R Gittleman "The African Charter on Human and People's Rights" (1982) 22 Virginia Journal of International Law667; Godfrey Musila "The Right to an Effective Remedy Under the African Charter on Human and People's Rights"(2006) 6 African Human Rights Law Journal 442; and J Thuo Gathii "Mission Creep or a Search for Relevance: The East African Court of Justice's Human Rights Strategy" (2013) 24 Duke Journal of Comparative and International Law 249. See American Convention on Human Rights 1144 UNTS 123 (signed 22 November 1969, entered into force 18 July 1978). 
responsible for crimes committed in former Yugoslavia and in Rwanda. ${ }^{35}$ The adoption of the Rome Statute in 1998, which established the International Criminal Court, represented the next step, although it has been subject to intense criticism in some circles. ${ }^{36}$ In parallel, a number of hybrid tribunals have been used to address specific situations to fight against impunity. Thus, the emergence of international criminal jurisdiction has gone a long way to impact the protection of the human rights of men and women by means of prosecuting, inter alia, crimes against humanity, war crimes, genocide and ethnic cleansing.

The presence of "judge" is significant and has far-reaching consequences in the field of international relations. First, as regards to human rights protection, the interests here safeguarded may become actionable and thus become "rights" in the technical sense of the term, evoking the possibility for the individual to seek cessation of the harmful act by the State; it provides for the victim appropriate compensation for the damage suffered. Secondly, the presence of a judge converts the pacta sunt servanda rule from (mere) ethical principle to a legally binding rule for States. Thirdly, and related to the one above, is that an ever greater number of states consider it logical and natural to subject the exercise of their sovereignty to control by a court of justice "external" to, and independent of, the State.

The presence of a "judge" thus denotes, in principle, a strong limitation of the sovereignty of States, and their respect for a rules-based system as the power of States is ever more bound by legal norms. Thus, in relations among States, it is no longer a question only of use and abuse of power but, first and foremost, of respect for the law. This is truly an "epochal" transformation. ${ }^{37}$

\section{$G$ The Limited Force of the UN system from 1945 to the Collapse of the USSR}

\section{What weakened the UN System}

In reality, the UN system, as set up in San Francisco in 1945, was, so to speak, "ontologically" weak due to the presence of certain incapacitating factors.

35 See Treasa Dunworth and Claire McGeorge "International Criminal Law" in Alberto Costi (ed) Public International Law: A New Zealand Perspective (LexisNexis NZ Limited, Wellington, 2020) 821.

36 See for example Alejandro Teitelbaum "Statute of the International Criminal Court: A Critique" (1999) 26 Social Justice 107.

37 All of this "apparatus" protecting human rights has nevertheless been of little or no avail in abolishing the systematic violation of such rights (for example, of women, or of religious freedom). The fact is that an alarming erosion of human rights is occurring also in States that champion those very rights: in the field of workers' rights, where social protection systems are eroding; and in the field of migration, where the borders of the richest States loom; and in the field of digital technology, with the onset of the risk of new forms of invasive monitoring and control of workers' performance, in terms of which (and especially in the gig economy) a new underclass is emerging. 
First, the UN system, including the UDHR, on the one hand, was created (and still works) to pursue universal values, and proposed some kind of supervision of the conduct of States by the international community. At the same time, though, it delegated to States the entire management of those same values, thus protecting to a large degree the sovereignty of States. For instance, the vote of one third of UN members represented in the General Assembly is sufficient to block any draft resolution discussed in the only plenary organ of the UN. Moreover, before the Security Council, the two-third majority rule prevails, but the veto of just one of the permanent members (the so-called P5: China, France, United Kingdom, Russia and United States) may paralyse any decision of the Security Council on substantive matters. All this means that the UN Charter is faced with a double limitation on its operation: it attempts to balance universal values and sovereignty of the State, while at the same time reconciling the somewhat "autocratic" element (the Security Council) with the democratic one (the General Assembly), in some way repeating the balance that in ancient Rome coined the famous formula Senatus populusque Romanus (SPQR): where the "people" (now the States) gathered in the General Assembly to counteract the "Senate" (now the Security Council).

Secondly, art 2(1) of the UN Charter reiterates the principle of "sovereign equality" of the members on which the UN is based, a principle that inter alia precludes the organisation's intervention "... in matters which are essentially within the domestic jurisdiction of any state". ${ }^{38}$ However, as we have just noted, the principle of sovereign equality proclaimed by the Charter is apparently contradicted by the actual distribution of functions by the Charter itself, which inscribes the predominance of the Security Council over the General Assembly. This has led authors such as Hans Morgenthau to talk about "sovereign inequality" of States, not of their "sovereign equality". ${ }^{39}$

Thirdly, the ICJ, the principal judicial organ of the UN, as indicated earlier, does not have compulsory jurisdiction over inter-State disputes. ${ }^{40}$ Consequently, one could say that it is not so much a matter of States being subject to decisions delivered by the Court, but of the ICJ being dependent on the decision of States whether or not to activate its jurisdiction by appearing before the Court. In practical terms, the ICJ Statute "configures" the relation between the Court and States according to the framework of optional acceptance by States of the competence of the Court, that is, according to a framework altogether compressed by the prerogatives of state sovereignty. Even though one could perhaps imagine that the drafters of the ICJ Statute might have expected, with the passage of time, a large number of States to accept the compulsory jurisdiction of the Court, this scenario never

38 Charter of the United Nations, art 2(7).

39 Hans J Morgenthau "The Problem of Sovereignty Reconsidered" (1948) 48 Columbia L Rev 341 at 353; and more in Hans J Morgenthau Politics among Nations. The Struggle for Power and Peace (McGraw-Hill Inc, New York, 1985) at 249.

40 Charter of the United Nations, art 94. 
materialised. Such a possibility might have made the ICJ an organ of "uniform" jurisdiction for all States underlying Kelsen's international law project.

Fourthly, there does not exist, within the UN system, a body empowered by the Charter to interpret the Charter itself and to establish the boundaries regarding the powers of its diverse bodies. The requests for advisory opinions before the ICJ do not amount to such. Neither did the Charter provide for an international police force distinct from, and independent of, the armed forces of the member States with the power to enforce the "resolutions" adopted by the Security Council.

Although it is principally this "ontological" weakness of the UN system, in terms of discharging its mandate to maintain international peace and security, that many commentators often emphasise, a more comprehensive assessment of the Charter also shows some of its merits.

\section{What strengthened the UN system until 1989-1991}

In its first 45 years of existence, what gave force and prominence to the UN as the system charged with keeping the peace was the terrifying prospect of a nuclear war that could result in the destruction of a large majority of the human race. No stakes could be higher, and the lack of any imaginable gain of such a confrontation for either side of the bi-polar world did lead to a clear disregard of the use of nuclear weapons, seen as disproportionate. The real risk of unleashing total "planetary" war thus incited States to accept the constraints imposed by the UN Charter in the peaceful resolution of international disputes.

However, the fear of a new world war and the angst of a nuclear catastrophe that it could entail were not sufficient to guarantee "median observance" of the UN system and the jus contra bellum norm contained in the Charter. After all, awareness that a new conflict could have had terrifying, devastating consequences was already obvious, but did not serve as a lesson, to the rulers of Europe after WWI, as potently stated by Sigmund Freud in his essay Das Unbehagen in der Kultur. ${ }^{41}$

41 Freud wrote:

The fateful question for the human species seems to me to be whether and to what extent their cultural development would succeed in mastering the disturbance of their communal life by the human instinct of aggression and self-destruction. It may be that in this respect precisely the present time deserves a special interest. Men have gained control over the forces of nature to such an extent that with their help they would have no difficulty in exterminating one another to the last man. They know this, and hence comes a large part of their current unrest, their unhappiness and their mood of anxiety. And now it is to be expected that the other of the two 'Heavenly Powers', eternal Eros, will make an effort to assert himself in the struggle with his equally immortal adversary. But who can foresee with what success and with what result?

The result, in Freud's view, was that soon Germany's aggressive and self-destructive instinct would erupt onto the international political arena and the life of all humankind would be scourged with another world war, one even worse - due to the moral and material damage it would cause - than the previous one. 
In addition to the fear of war, starting from the mid-1940s, there arose a balance of power at the global level between the western world and the Soviet Bloc. In this way, two stabilizing Powers, the United States and the Soviet Union, assumed influence over a vast number of governments, curbing any aggressive impulses by means of a highly special criterion of international relations defined as "deterrence". The Korean War (1950-1953), the invasion of Afghanistan by Soviet troops (19791989), as well as the Cuban missile crisis (1962), all constituted the most critical moments of the Cold War and already then demonstrated that the UN was not able, on its own, to avert war.

Only the synergy between the fear of nuclear war together with the stabilizing factor of mutual deterrence succeeded in ensuring "normal" compliance with the UN system, balancing the debilitating factors operating within it. Hence, the recourse to violence by States was kept during that period within limits that should be deemed "functional" in the framework of an inter-State society.

\section{PART TWO: FROM WORLD ORDER TO WORLD DISORDER: THE WORLD WITHOUT COMPASS IN WHICH WE LIVE}

\section{A The Great Illusion}

While it is slowly and with a certain degree of reluctance that States accepted to comply with the norms and principles of the UN Charter, the sudden collapse of the Communist bloc in the late 1980s and early 1990s gave rise, in the West, to a "Great Illusion". No longer, it appeared, was the world a military arena where conflicting and reciprocally incompatible societal models clashed. As a result, Western values and institutions started to spread around the world. In the area of political theory, this "Great Illusion" was illustrated in the work of political scientist Francis Fukuyama. ${ }^{42} \mathrm{He}$ went so far as asserting that we were on the brink of the "advent of the supremacy of Spirit theorised by Hegel" and that we had reached the "End of History", there being no alternative to the liberal democracy and capitalism of the Western tradition.

This state of affairs did not last long. It became clear almost immediately that the United States was "the linchpin of the hoped-for new world order", and so it would have to assume "the role of the world's police force". ${ }^{43}$ However, it was not strong enough to shoulder the burden of "overseeing" a stable uni-polar world. ${ }^{44}$ The terrorist attacks of 11 September 2001 laid to rest the "Great Illusion". From that moment onwards, it became clear to everyone that the "new world order" envisaged by President George Bush Sr was nothing more than a "new world disorder".

42 Francis Fukuyama The End of History and the Last Man (Penguin, London, 1992).

43 Andrew Heywood Politics (2nd ed, Palgrave Foundations, New York, 2002) at 134.

44 In this regard, see John J Mearsheimer The Great Illusion - Liberal Dreams and International Realities (Henry L Stimson Lectures series, Yale University Press, New Heaven and London, 2018) at chapter 1. 


\section{B The Global World, Somewhat Dangerous and Chaotic}

To identify the causes of what can be defined as the "misgovernment of the world", one must go back to the problem of the lebensraum (living space). This geopolitical concept was popularised in Germany, was an objective of Imperial Germany during WWI, proliferated in the interwar period and had its climax in Nazi propaganda to defend German territorial expansion and Central and Eastern Europe. It was based on the idea that the "living space" was the territory necessary for national existence or economic self-sufficiency.

After WWII, national borders were perceived, to some extent, as an obstacle to the realisation of the wider goals of the geopolitically homogeneous but opposed East and West. Grosso modo, there was now a Communist-ruled world and a Western sphere regulated by liberal governments. In between sat the so-called "Third World", still in search of its own enduring future and often the pawns in the proxy conflicts of the East and West. As the Cold War ended, the problem of lebensraum resurfaced, but in an entirely different way. The quest for "living space" was now longer - as in the past - an issue for States through the lenses of the economy, finance and individuals. In a globalised world, lebensraum increasingly referred to the conditions needed for the development of individuals, the growth of financial resources and profitability of business, in a world without borders.

However, the international community lacked a proper framework capable of steering such developments in an orderly manner. Neither was there the necessary political foresight. It was for these reasons that the global market had free reins to deliver a world order where the ideas of superpowers could prevail over those of smaller states, and the goals of powerful corporations over the needs of smaller economies, although corporations could not generally disregard local laws. Equally, the forces of the market would dictate where people, individually or in groups, would settle down, in line with the opportunities or advantages available to them, leading to economic migration and its possible effects. In effect, this human "nomadism" of single individuals or small groups seeking a "living space" translated, through a series of factors of various nature, into an immense wave of migration involving millions of people. Two of these factors were of an essentially political character.

The first relates to the "conquest" of vast territories in recent years by new political non-state actors who resolved to bring about, by any means (including terrorism), radical changes. For instance, attempts by ISIS to ensure full enforcement of the Sharia by means of the elimination of all those elements responsible for the contamination of a sacred, immutable tradition, threatened by ideas, values and institutions from the West.

The second factor, which added to the first one, often contributes to the oppression of peoples, is the emergence, post-Cold War, of "second-class" Powers such as Russia, China, France, and now Turkey under Erdogan. Each of them pursues strategies more often than not confused and wayward, and often oblivious to the consequences in the medium and long term, and they seek to expand their 
sphere of influence, often fuelling "minor skirmishes" into major conflicts, mainly in North Africa and in the Middle East.

In this way, whole populations have found themselves, almost overnight, in situations utterly unbearable. They have been caught in the political upheavals in Iraq (2003) and Libya (2011) following the violent "regime changes" in those countries; they have lived through the civil war that has caused significant bloodshed in Syria - and has been dragging on since 2011. Let us not forget either the fierce and violent campaigns of ISIS, led by Abu Bakr al-Baghdadi:

Caliph Ibrahim commander of the faithful, who one day, in the Grand Mosque of al-Nuri in Mosul,

declared war on Christendom and on the West with the words: 'one Book guides us, one sword defends

us'.

This situation of global disorder - left to fester far too long - has caused incalculable damage, the result of an almost uninterrupted sequence of colossal errors committed by various politicians in the United States, NATO and the EU in developing policies that have had the effect of destabilising entire geopolitically important regions of the world. These are areas have rapidly been transformed into scenes of unprecedented violence from which multitudes of men, women and children have fled. Among those must also be mentioned Brexit, whose consequences in the long term may lead to the weakening of democracy on the European continent. In the destinations towards which migrants are heading, a defensive instinct is mounting. The entire architecture of values of the West - democracy, universality of human rights, solidarity among peoples - is coming under severe strain. ${ }^{45}$

Added to these disturbing factors is a third one, nationalism, manifested, for instance, in Donald Trump's "America First" slogan. This variant of nationalism - "conservative" nationalism - presents itself as a blend of the following: first, protection of the national identity, often through antiimmigration policies; secondly, revival of State sovereignty through anti-supranational politics; and, thirdly, economic protectionism. ${ }^{46}$ Now, this type of nationalism, by its very characteristics, threatens to undermine the fundamental ideas (and ideals) of the world order born post-WWII, especially the 1944-1948 period. They include the creation of the UN, an organisation born out of an unwavering faith in the future and intended to construct a framework of reciprocal solidarity among States and

45 On this issue, see Mario Patrono and Rebecca McMenamin "Mass Migration. An Ordeal by Fire for Universal Human Rights" in Luca Albino, Francesco Alicino, and Felice Ancora (eds) Scritti in onore di Sara Volterra (Giappichelli Editore, Turin, 2017) 719.

46 Heywood, above n 43, at 114-15. On United States President Donald Trump's attitude to International agreements, see Jean Galbraith "Contemporary Practice of United States Relating to International Law" (2018) 112 Am J Int'l L 734; Jean Galbraith "Trump Administration Announces Withdrawal from Four International Agreements" (2019) 113 Am J Int'l L 131; and John B Bellinger III "The Trump Administration's Approach to International Law: Are We Seeing a Turn for the Worse?" (2019) 51 Case Western Reserve Journal of International Law 12. See also Stephen P Mulligan The United States and the 'World Court' (Congressional Research Service, 17 October 2018). 
peoples; the concept that human rights are universal and inherent to the person; and the idea of an open free market.

The combination of these factors - multipolarity, Islamic terrorism, neo-liberalism and nationalism - has transformed the (former) "global order" into one "somewhat dangerous and chaotic". 47

\section{PART THREE: ONCE COVID-19 IS OVER, TOWARD A CHANGED NEW GLOBAL ORDER?}

\section{A Before the Pandemic}

In 2021, the Planet is a dangerous place, not only for the reasons addressed above, but also due to the inequalities that might derive from a crisis facing economic globalisation, centred on the (in)efficient functioning of the WTO. The world is thus "somewhat dangerous and chaotic" in a wider and more complex sense. No one can fail to see the global dangers we face. Long-term processes, like the destruction of the environment, is one such danger. The risk of pandemics is another threat to our future. Armed conflicts too are a terrible reality in a world where the international system of balance of power politics is both multipolar and precariously poised. ${ }^{48}$

The best line of defence against these dangers - with the aim to avert them, reduce their impact or repair their consequences following their occurrence - still resides today in the institutionalised global order whose principal pillars are the UN and its organs, including the ICJ, along with the IMF, the World Bank, the WTO and, at the regional level, the EU. ${ }^{49}$ That said, it must be acknowledged that that the UN system and other international organisations, to fulfil such role, must be reassessed and their functions improved in order to enhance their efficacy.

Thus, the scenario shaping up at the end of 2019 was very complex and anything but reassuring, and that's before the pandemic hit.

47 Holly Ellyatt "'The international system is somewhat dangerous and chaotic,' Condoleezza Rice warns" CNBC (online ed, United States, 11 November 2019) <www.cnbc.com>.

48 These dangers, including pandemics, were identified by Noam Chomsky "How to destroy the future" The Guardian (online ed, Manchester (UK), 4 June 2013) <www.theguardian.com>. See also John J Mearsheimer The Tragedy of Great Power Politics (1st ed, W W Norton and Company, New York, 2001) at 357. Ban KiMoon, then UN Secretary General, opening the debate at the UN General Assembly, 4 May 2015, warned that "Conflict, poverty, violence, exclusion and disasters are grave and growing problems", adding that "no country was immune from global threats, and no one country - however powerful - could respond alone to such problems": Ban Ki-Moon, Secretary-General "Remarks at a high-level General Assembly debate on Strengthening Cooperation between the UN and Regional and Sub-regional Organisations" (4 May 2015).

49 Compare Nico J Schrijver The Future of the Charter of the United Nations (vol 10, Max Planck Yearbook of United Nations, 2006) at 1-34, who over a decade ago defended the view that the overall UN organisation system should be dismantled and replaced by something more suited to face the problems confronting the international community. 


\section{B A Micro-Organism of a New Type Attacks Humankind Inflicting Heavy Losses. An Answer to Francis Fukuyama's Theory on Covid-19 Impact and Politics}

Suddenly, at the start of 2020, a terrible pandemic materialised in the devastating form of a microorganism of a new type, Covid-19, wreaking such havoc that no prophet of doom, no sociologist, politician, economist or scholar of international law could ever have foreseen.

On the urgency scale, safeguarding public health obviously came first. In this regard, the political management of the pandemic showed us, according to Francis Fukuyama, ${ }^{50}$ that faced with severe emergencies, democracies can resemble autocracies, with a centralisation of powers in the hands of the Executive equated by a stark weakening of the organs able to control these powers - the courts and Parliament. In a situation of grave emergency, argues Fukuyama, the real differences are not between democracies and autocracies, but rather between governments that adopt proper measures, that is, decisions able effectively to tackle the emergency, and those that do not. ${ }^{51}$

Fukuyuma's proposition contains glimpses of truth, but it appears a bit descriptive and slightly superficial, both in its accounting for the factors and for the context on the basis of which the decisions taken by governments might be defined as "right" or "wrong", and in the parameters used to define what is "right" or "wrong". On the one hand, in concreto, decisions objectively said to be "right" or "wrong" concerning the looming pandemic were taken equally by democracies and autocracies, without any relevance ensuing from the type of regime - democracy or autocracy. For instance, certainly "wrong" was the strategy of containment of the pandemic adopted by the political decisionmakers who, heading democracies or regimes under one-party dictatorships, initially and for too long ignored or underestimated the tragic news coming first from Wuhan (I am referring here to China and then Italy, the first Western State to be severely struck by Covid-19). Other governments radically changed their strategy when it was already too late (such as the United Kingdom and the United states). Conversely, "right" was the decision taken by other democracies and autocracies who consciously reacted at the first inkling of danger, thereby averting the uncontrolled spread of the virus (New Zealand in the former category, Cambodia in the latter).

On the one hand, Fukuyama omits consideration of the fact that democracies differ from each other, not least in the way political decisions are taken, for instance, according to the strong or weak sense of responsibility their citizens have towards the nation as a whole, if not towards humankind as a whole. Then, "right" was the decision, on the early flare-up of the pandemic, to consider this element; "wrong", the negligent decision not to do so. Thus, on the one hand, the democracies of

50 Francis Fukuyama "The Thing that Determines a Country's Resistance to the Coronavirus - The major dividing line in effective crisis response will not place autocracies on one side and democracies on the other" The Atlantic (online ed, Boston (US), 30 March 302020) <www.theatlantic.com>.

51 Fukuyama, above n 50. 
Japan and South Korea, whose citizens have a very strong sense of responsibility towards the collective well-being, adopted a "mixed" system of containment, that is, a "weak" lockdown; on the other hand, Italy, adopted (likewise correctly) a "strong" lockdown system.

Reasoning like Fukuyama, in fact, we might overlook the consideration that in many of the most powerful western States - the United States of America and Germany, for example - the power that the federal Executive must take into account, even during public emergencies, and the views of internal federal units - States, Länder. These often overtly contest the need for "national" emergency measures, or require the federal government to "negotiate" their implementation. Our point is that in most democracies, some decisions taken to tackle grave emergencies may be "right", others may be "wrong". I add that the assessment depends very much on the point of view of the observer: in the case of Covid-19 for instance, what is the "right" balance between safeguarding health (a "sacrosanct" right) and protecting the population from the ensuing disaster of the pandemic for the economy and the labour market? Above all, one cannot dispute the fact that as the pressure of the emergency gradually dissipates, scrutiny over the exercise of powers shall revolve back to other branches of government in democracies. Thus, control over what might be termed "autocratic" measures adopted during the worst phase of the pandemic will again be placed under the microscope of judicial and parliamentary oversight. More and more, the Executive will be called to answer in public a posteriori for the exercise of its powers. However, in autocracies, this moment takes place in the obscurity of the arcana imperii. Where governments in democracies might resemble those in charge of autocracies - but this is an aspect that Fukuyama does not discuss - is in relation to the "serious" emergency and the need to exercise "exceptional" powers to fight it. Such powers may entail suspensions or at least strict limitations of fundamental freedoms, limited in time to the duration of the emergency. But when the exercise of special powers become indefinite and authorises a derogation sans fin of the normal balance of power; this certainly poses a serious problem for democracies. ${ }^{52}$

\section{The Actors of the Economic Recovery}

To the urgency of tackling the health emergency, we must not forget to add the need to manage the economic consequences of the pandemic. In fact, the measures necessary to contain the virus have triggered an economic downturn almost everywhere. Covid-19 represents an unprecedented total crisis - novel by its nature - that occurred in the form of a massive halt in production and, thus, a shock to the supply chain: by the extent of its global impact; and by its very magnitude. ${ }^{53}$ The major

52 See for example Dean R Knight and Geoff McLay "Is New Zealand's Covid-19 lockdown lawful? - an alternative view" (11 May 2020) UKCLA <www.ukconstitutionallaw.org>.

53 According to data furnished monthly by the principal economic institutions of the world - IMF, World Bank, European Central Bank, Bank of England and US Federal Reserve, losses due to Covid-19 amount to several trillion dollars. For instance, according to the calculations of the Federal Reserve, released on 29 July 2020, in the second quarter of 2020, the United States' GDP decreased, on annual basis, by 32.9 per cent, while in the Euro zone, the setback of the economy was less abrupt (12.1 per cent), but still very worrying due to the 
efforts of governments are aimed, for the moment, at limiting such a dramatic impact and embarking on a gradual recovery. Alongside national governments, relevant institutions formed around the UN after WWII, such as the IMF and the World Bank, have also addressed the pandemic. The institutions created within the EU have also played a role; after all, the EU too is an international organisation emerged out of the spirit of peace and justice that animated the creation of the UN.

At the outset, a preliminary observation might be useful. In the field of recovery policies - the immediate and gravest concern of national governments and international organisations in the wake of Covid-19 - one needs to be aware of the fact that this is a different kind of crisis than previous financial crises. It is not just a problem of aggregate demand or simply a matter of GDP. The problem is far vaster and with tentacles spreading to the poorest nations. At this point, it is not a matter only of first, restoring, then stabilising, the conditions for the minimal subsistence of the people living in the least developed States, of safeguarding the individual's "dignity of living"; nor is it a matter in developed economies only of restoring an acceptable level of economic well-being. It is a matter, more generally, of working towards a more acceptable distribution of wealth within States and among States, as well as ensuring a quality of life in its various aspects. To be up to this daunting task, the international economic and financial organisations require, first of all, more resources than those currently available to them. Metaphorically speaking, one could say that the budgetary policy - fiscal as well as expenditure - could be compared to the banks of a waterway. While the monetary policy is like a dam upriver that determines the water flow of the river, if at this point the river bed undergoes a large increase, so that the river banks get shifted further apart, the mass of water that the river needs to fill it will also have to be bigger. Thus, a greater water flow will have to be released from the dam. Now, this is a crucial point that concerns, notwithstanding their different tasks, both the IMF and the World Bank. We shall see immediately below the (enormous) problems that in this context derive from the economic and financial framework of the EU.

\section{From Agents of Planetary Neo-liberalism to Protagonists of Global Social Justice}

\section{The IMF and the World Bank as major global actors}

Let us look first at the IMF and the World Bank, focusing our analysis on the IMF that, of the two, is the one experiencing greater problems. The IMF intervenes to help States that need to

lesser recovery capacity of the European economy compared to the US economy. According to the Federal Reserve Bank of St Luis:

... the immediate consequence of closing many sectors of the economy was a significant decline in GDP growth, which was as large as 8.7 percentage points for the median middle-income countries. Wealthier countries suffered a bit less, with a median of 6.4 percentage points, mainly as they were able to recover by the end of 2020 .

See Juan M Sanchez "Covid-19's Economic Impact around the World" (11 August 2021) Federal Reserve Bank of St Louis <www.stlouisfed.org>. 
restructure their public debt when it gets too burdensome. Created for a specific purpose - to maintain economic stability - the underlying "philosophy" of the IMF is that economic stability fosters growth, which in its turn favours prosperity. ${ }^{54}$ But, even accepting these goals - from stability to growth, and from growth to prosperity - it was clear to the IMF Executive Board, already before Covid-19, that growth was not possible without expansive monetary policies, able to sustain the demand that is somewhat the "accelerator pedal" of growth. This structural deficiency in aggregate demand depends, in large part, on the fact that income distribution is highly unequal, favouring the higher income bracket of the population. In the United States, in 2016, one per cent of the population owned 20 per cent of the national wealth, that is, of total GDP. ${ }^{55}$ Analogous trends, albeit less pronounced, may be found in Europe and developing economies. This gives rise to a shortage of aggregate demand, due precisely to the limited economic capacity from an overwhelming majority of the population. ${ }^{56}$ And this also underlines the need for more expansive monetary policies, founded on public and private debt, but these monetary policies should exclude states with very high public debt, that is, those States which have no "fiscal capacity". The most obvious "therapy" for symptoms of this kind revolves around the necessity to rebalance income distribution. In reality, even before the outbreak of Covid19, it was clearly understood that to enable the economy to walk on its own (and not thanks to the artifice of injecting mountains of money into the system), it was necessary to reduce this inequality by means of a manoeuvre of social justice. This is the first point to bear clearly in mind.

The second point regards the resources available to the IMF. The IMF has to be ready to come to the rescue of states most heavily struck by the pandemic. In order to be able to do this, the IMF must have sufficient means. On 18 December 2015, the Congress of the United States finally approved the reform of the quota system that had already been approved by the IMF in 2010. This meant doubling the capital endowment of the IMF, bringing it up to about USD669bn. Despite this sizable increase in the amount of available capital, the IMF remains too "poor" as against the formidable requirements of the present situation. More specifically, the scarcity of available resources relative to the size of the world economy compels the IMF to resort on almost every occasion to the procedure of "exceptional" access. This procedure requires that IMF loans are subject to particularly severe criteria; that is to say, restructuring public debt to make "highly probable" transactions, rendering the debt sustainable. All of this, however, means that the State that needs the loan is compelled to endure, in the short and medium term, enormous social costs that may prove unsustainable. Here then lies the need for policies for the redistribution of wealth favouring the weaker sections of the population; and this is an aspect

54 See International Monetary Fund "The IMF at a glance" (3 March 2021) <www.imf.org>.

55 For 2020 figures, see Nick Hanauer and David M Rolf "The Top 1\% of Americans Have Taken \$50 Trillion From the Bottom 90\% - And That's Made the U.S. Less Secure" Time (online ed, New York, 14 September 2020) <www.time.com>.

56 And this is the view expressed by Raghuram Rajan, former chief economist of the IMF, now Governor of the Bank of India, in his book: Raghuram Rajan Fault Lines: How Hidden Fractures Still Threaten the World Economy (Princeton University Press, Princeton, 2010). 
that must by no means be underestimated. Hence, the limited resources available to the IMF and related consequences.

There is also a third aspect to consider regarding the close dependence of the IMF on the United States. To explain: Because of the reform of member States' quotas - a reform that took into account changes in the size of the economies of the individual member States - the influence of emerging economies on decision-making procedures was increased, in particular that of China and of Russia. In turn, the influence of advanced economies diminished, along with the decision-making power of the EU member States. What did not change, though, was the dominant role of the United States in the IMF. Thanks to their quota, which is sitting over 15 per cent, the United States maintains a veto power concerning a set of strategic decisions of the IMF. Also relative to this, the United States Congress - a major shareholder in the IMF - has demanded, and obtained, in the strictest confidence, files pertaining to exceptionally high loans before their discussion before the IMF Board. In this way, the Congress is the sole Parliament, among the member States, to enjoy this privilege. This situation of pre-eminence, conferring on the United States a conditioning role in the balance of the international economy, leads to confounding the interests of that great country with the interests of humankind at large.

Thus, in order for the IMF to be able, alongside States, to manage the situation, the IMF (but the same holds, mutatis mutandis for the World Bank) is in need of reforms that are both urgent and thorough. These reforms must, of necessity, cover: available resources; independence of specific national interests in order to be able to operate according to rules of impartiality and with the common interest in mind; and its "mission". It is only by doing so that the funds provided to States might, therefore, be contingent on the commitment of the borrowing State to mould its national economy ensuring a sustainable growth that includes social needs.

In a word, it is necessary to rethink the purpose of the leading economic and financial organisations, such as the IMF and the World Bank, to enable them to become vectors of a new economy aimed at fostering a more equal income distribution. In this way, they may lay the foundations for a growth that considers the needs of the population, and for an extension of the democratic process, to societies previously governed by non-democratic or pseudo-democratic governments. Such achievements, naturally, require that governments know how to construct the necessary common political capital. In fact, neither the IMF nor the World Bank can act without the legitimacy that derives from the political support from governments, whose legitimacy, in the end, is based on democratic and open national elections.

\section{The EU as a regional supranational organisation}

Turning now to the EU, the violent impact of Covid-19 on the economic situation in the member States (and also on their dealings worldwide) has elevated the two main structural defects in the economic and financial framework of the EU to the surface, and in particular, of the Economic Monetary Union (EMU). The first (and most serious) defect arises in the relations between the EU 
and the member States of the Eurozone, from the disarticulation of the overall economic policy in two separate spheres: on the one hand, monetary policy transferred from the member States to the EU and administered by the European Central Bank (ECB); and, on the other hand, fiscal and budgetary policy, which remains in the hands of the member States. These two elements represent, so to speak, the two legs of general economic policy. Thus, both the EU and the member States take one step on only one leg, then leaning on the crutches of the macroeconomic discipline drawn up in the Eurozone Treaty. Now, it is certainly possible to walk on one leg aided by a crutch, but over short distances and on terrain free of obstacles. When however, a crisis suddenly arises, where nimble movements, swift spurts, rapid changes of direction or other such actions are needed, then someone walking on only one leg is at a serious disadvantage. Now, leaving behind our metaphor, if it is true that tackling any grave and prolonged economic crisis (as with Covid-19) requires that governmental institutions have available to them all the powers connected to the monetary, fiscal and budgetary levers, it can be asserted, with good reason, that the monetary union is least suited, because of the unusual way in which it was set up, when the economy is caught in a storm and must navigate rogue waves.

The second structural defect of the EU in the economic and financial field arises from the absence of an "emergency clause" capable of confronting structural crises of the entire EU economy. What is lacking is a "risk contingency" plan. There is, it is true, a "disaster clause" in the Lisbon Treaty of $2009 .{ }^{57}$ Its art 122.2 provides that the EU may grant, under certain conditions, its financial assistance to a member State, when such a State is in difficulties or is seriously threatened with severe difficulties, whenever those difficulties derive from a natural disaster or from exceptional occurrences that spin out of its control. But, as can be observed, the financial assistance mentioned above refers exclusively to difficulties encountered by individual States; it does not at all pertain to a situation of economic shock afflicting, even if at different levels of gravity, all EU member States. The EU, having been impelled to navigate the stalemates of the Treaty on the Functioning of the European Union (TFEU), and in anticipation, in the not too distant future, of the consolidation of the monetary and the fiscal and budgetary policies, has come to adopt an intervention strategy organised around three guidelines. First, based on a stretched interpretation of TFEU art 122.2, the EU has adopted the "Pandemic Crisis Support", a long-term credit line at preferential rates available to the Eurozone member States, allocated to cover direct and indirect healthcare and prevention costs. The Pandemic Crisis Support constitutes an updated and revisited version of the European Stability Mechanism (ES), which is itself connected to art 122.2 of the TFEU. A second intervention guideline is provided by the Outright Monetary Transactions (OMT), deemed legitimate by the Court of Justice of the European Union and by various national constitutional courts. The OMT is a special programme that the ECB can decide to activate in favour of States in difficulty, and consists of the purchase of State bonds, without limits if necessary. Finally, there is the Recovery Fund, that is, the allocation by the EU of an enormous sum of money - about $€ 750 \mathrm{bn}$ - for distribution among the member States worst affected

57 Treaty of Lisbon 2007/C 306/01 (signed 13 December 2007, entered into force 1 December 2009). 
by the pandemic and the ensuing disastrous economic consequences. The use by the beneficiary States of the sums received - in part as loans at highly reduced interest rates, in part as grants - is subject to the control of Ecofin, the organ in charge of verifying the conformity of the reforms carried out at the national level thanks to the funds received, with respect to the stringent spending criteria laid down by the EU.

It (may) not seem too bold to expect the EU, finally, following the gravest economic disaster of modern times, and in order to limit future crises, to take a decisive step towards setting up the framework for the economic federalisation of Europe.

\section{E The Road Ahead Seems Obstructed}

Remedying the dire economic, political and social consequences of Covid-19, which pushed back so rapidly and drastically living standards by years let alone decades, mined optimism and stability, almost deleting - among many people - the very word "future", is the hard problem that national governments and the international community is now facing. When, sooner or later, a sense of normality will return, it is hoped that the distribution of wealth will be somewhat less unequal, and the level of awareness of the problems we face will be somewhat greater among humans, everywhere.

At that point, there may be in place the conditions - psychological, cultural, and of necessity - to address the problem jointly. To quote the enlightening words of Her Majesty, the Queen Elizabeth II in her special address to the nation on 5 April 2020: "This time we join with all nations across the globe in a common endeavour"; 58 the problem of healing the world of the pathology that afflicts it, war: between nations, and against Nature.

No doubt, on this path, we shall face immense political obstacles, far more than those confronting us in our attempts at economic recovery, post-Covid-19. Lurking is a struggle between different aims and perspectives that may sometimes appear incompatible.

On one side, there is the trend found in the label "Back to the Old Times". This movement advocates the disempowerment of the pillars of the international order post-1945. Pushing in that direction is the "conservative" nationalism symbolised by Trump's slogan "America First". In the United Kingdom, the government led by Boris Johnson has pursued similar goals, albeit at a more cautious level. This type of nationalism may be characterised by some specific features, already mentioned earlier in this article: reinforcing State sovereignty, and, at the EU level, weakening the measures "imposed from Brussels"; anti-immigration policies; protectionism; and, in certain circles, limited awareness of environmental concerns. Each nation defends on the world stage its own interests and develops its own resources, and bilateral relations are favoured over multilateralism. Indeed, much energy is engaged towards weakening international organisations and, in particular, the EU.

58 See "Coronavirus: The Queen's broadcast in full" BBC News (online ed, United Kingdom, 5 April 2020) <www.bbc.com>. 
Brexit, expressing the will of the majority of the British people in 2016, is set within this framework. "My Country First" can be defined, in geopolitical terms, as "Politics and Bilateralism First".

This trend - "conservative" nationalism - does not take into account the fact that there are matters of international concern, historically collective perspectives, that are so to speak "supranational", that stretch across borders. Such matters, by their very nature, elude control by individual States. Confronting climate change, other environmental threats and over-exploitation of natural resources through national policies is insufficient. Equally, migration problems and pandemics cannot be properly tackled through national policies alone. Such matters will assume an ever greater place, and their effects have a more poignant impact on the Planet if we do not address them now by means of appropriate and timely wide-ranging solutions. Certainly, David Held was right when he wrote: "Not all environmental problems are, of course, global; such an implication would be entirely false". ${ }^{59}$ However, it is also true, Held added, that "there has been a striking physical and environmental shift in the circumstances - that is in the intensity and extent of environmental problems - affecting human affairs in general". ${ }^{60}$

Directly opposed to "conservative" nationalism is neo-liberalism. Albeit fully cognizant of the grave emergencies facing humankind, neo-liberals are convinced that nothing else need be done, after surmounting the obstacles laid by Covid-19, than to resume treading the same path on which we were proceeding pre-pandemic, a sort "Business as Usual" approach. The argument put forward is simple: the road we have trodden so far is the one along which we have painstakingly made the achievements of these last few centuries, that have made life better, delivered greater well-being, opportunities for growth, mitigation of diseases, civilisation, and the extension of basic rights. In this way, however, the neo-liberals do nothing but hide behind the great, indisputable merits of capitalism, but also the most ruthless, truculent version of capitalism. When the Soviet Union imploded, the competing economic model - capitalism - had before it the choice to pursue one of two routes. One that led towards the prospect of sustainable development with a social dimension, towards greater attention to safeguarding the environment and the implementation of forms of social cohesion, indispensable elements of every developed society. The other route, the one which capitalism set for itself, is the trajectory of an economy entirely based on the idea of continuous and unlimited "growth" or development, deregulation and reduction of the State to the role of "night-watchman" with competition as the only criterion for organising social and economic life. The consequences of all this manifested themselves rapidly, as a growing and by now iniquitous and intolerable inequality in income distribution within States and among States. So, for example, the IMF calculated - as we already reported above - that in 2019 , one per cent of the United States population owned 20 per cent of the nation's wealth, whereas in 1980 it owned eight per cent. While some States and regions, the

59 David Held "The Changing Contours of Political Community: Rethinking Democracy in the Context of Globalisation" (1999) 46 Theoria 30 at 37.

60 David Held Models of Democracy (2nd ed, Polity Press, Cambridge, 1996) at 158 and 159. 
most industrialised and developed economies, have seen a substantial growth in the production of income - albeit often poorly distributed - other States have effectively been excluded from a generalised improvement of their economy and have even suffered a deterioration of their living conditions. In States and regions which are still lacking the most basic health, food and lodging necessities, over one billion people are forced to survive on an average income of a little over three dollars a day. All of this has provoked disastrous consequences at the human level.

However, the greater threat is that the "business as usual" approach might lead humankind to destroy our Planet. The neo-liberal response derives from the conviction that where the forces of market are unable, on their own, to rectify the situation, science and technology will. This conviction is puzzling for two reasons. First, this sounds more like wishful thinking; that we can tackle the problem by using "renewable" energies (solar and wind energy, for instance) and thus replace natural resources that pollute or are gradually depleting the environment. Secondly, that science (together with technology) is able to repair any damage that humans might inflict on the natural environment, to solve every problem caused by our abuse of nature, can be very reassuring, but it is not true. Scientific research is certainly in a position to aid and back political actions for fighting environmental degradation in its various aspects, however, it cannot dictate guidelines steering economic development and policies in the direction of "sustainability". It will always fall on politicians, perhaps directed by economic and other concerns, to establish the degree of risk that we can accept in exchange for our freedom and well-being. Science can come to the rescue only if, and when, politics calls for its help; and it is highly probable that the neo-liberal political class will seek its help only once it is too late. However, Covid-19 has shown that although Science may be in a position to assist decisionmakers when facing a crisis, it takes time to satisfactorily tackle new, deadly viruses or bacteria. But Science has its limits. If it can - maybe - help in ensuring a better protection for the environment or against pandemics, there is little it can do in relation to other serious situations, like large migration waves or armed conflict.

In contrast, others advocate consensus among States for the adoption of common rules that can be implemented in their domestic law. This approach amounts, in practice, to States "ceding" portions of their sovereignty. This approach seems the most realistic at first, but it can also be said to be utopian. The realistic character of this approach is demonstrated by the fact that it emerges from the mindset of informed public opinion witnessing crises of all sorts across borders and pushing States to address the needs of the global population. The utopia hiding in this approach consists in the temptation of imagining that today - as some imagined at the end of WWII - that a world government is just around the corner, if we really want it. ${ }^{61}$ It is not so, it cannot be so, as there is too often a chasm between

61 The Catholic Church ("catholic", let me remind you, means "universal") contended, during the global financial crisis, that certain problems affected the whole human race, and that it might be necessary "one day" to create "a public Authority with universal jurisdiction" operating on the basis of the subsidiarity principle, ad subsidium: Pontificial Council for Justice and Peace Towards Reforming the International Financial and Monetary Systems in the Context of Global Public Authority (24 October 2011). One is reminded that the 
globalisation of ideas, on the one hand, and, on the other, the traditional, parochial way that makes us look at challenges through a regional or national lens. One can say that the latter way of thinking is proving to be increasingly dysfunctional with each passing day. However, adjusting our approach to the magnitude of problems the Planet faces is a lengthy undertaking, perhaps impossible to realise. In other words, we only now realise that there are imminent global risks that no nation, no people, can tackle alone. Thus, realisation is dawning that joint policies are needed. However, what is lacking is the mindset necessary "to work together as one". The creation of a world government, if we want to be realistic, is still very far away, without the assurance that it would truly be an asset to humankind. Truth be told, the relations among States are still steadfastly based on the principle of sovereignty, in the same way that the life of individuals is based on the principle of private property. Every limitation of sovereignty - what is happening in Europe is its eloquent demonstration - is accepted by States only under certain conditions, and in any case, always with great difficulty. We must, therefore, avoid being dragged into a vortex of sententious abstractions.

\section{F Thucydides or Utopia, Humankind at the Crossroads}

When considering change, one further difficulty arises. In the post-pandemic world, there will inevitably be competition among those that are nevertheless interested - at least in theory - in making a contribution to the construction of a world able to provide global solutions to global problems, between two mindsets. One has as its great defender Thucydides, the first known writer about a contagious disease. In 430 BCE, during one of the best-known armed conflict of the time, Sparta's lifelong enemy, Athens, was struck by the plague. It was a devastating occurrence, which Thucydides recounts with his customary meticulous precision in his History of the Peloponnesian War. ${ }^{62}$ Thucydides had precise ideas about human nature, arguing that humans are unable to learn the lessons of History or, if they do understand, do not know how to remember same. Thus, for Thucydides, humans are destined to learn nothing from History and every generation will repeat the same mistakes, injustices and barbarities. Champion of the second approach is Immanuel Kant, who, at the end of the 18th century, argued in his Perpetual Peace that stable peace can come only when all States are republics governed by citizens who see the security of their property occurring only under the universal rule of law, rather than by proprietary rulers who can always see a neighbouring State as a potential enemy. ${ }^{63}$ Hence, citizens of a democratic republic are less likely to support their government

Catholic Church, following the Concordat of Worms (1122), aspired to the ascension of an order based on two "universal" authorities: a spiritual leader, the Pope; and temporal ruler, the Emperor - the former ancillary in character. Now, such a "reading" of the Pontifical Note would be contrary to the intentions of the drafters of that document. In reality, the profound secularisation of western society, let alone the fact that in the meantime the Catholic Church has almost entirely lost its influence of times past, are all elements that taken together ensure that the integration of the Catholic Church with the State that obtained in the darkest times of the Middle Ages cannot ever be replicated, or that it might in any way be analogous to that model.

62 Thucydides History of the Peloponnesian War, Book II (431-432 BC) 3.87.

63 Immanuel Kant Toward Perpetual Peace and Other Writings on Politics, Peace, and History (1724-1804). 
in a war. He thus yearned for the "public" use of reason, as virtually universally accepted as the premise for a utopian world in which women and men are fellow occupants of the Planet and citizens in a common global order. Compare the situation today, where some say that "Once the wounds have been healed, nothing will change, it is impossible to change things, there are too many forces stronger than us at play. Nothing will change". ${ }^{64}$ Conversely, others believe that "Nothing will be the same as before. The world must change, and it will change. We must build a better world for ourselves and for the future generations". 65

Yes, we can. No, we cannot.

Whatever vision shall prevail will have implications in geopolitics. However, the "future" is already here - look at sea level rise and climate related events. We face so many challenges now - we require solutions and the means to realise them.

\section{G Peace among Nations as End and Means}

If we are unable to take care of our Planet, then we are not worthy of the name Homo Sapiens. Faced by humankind's aggressive behaviour, nature produces certain antibodies that at times may take the form of a virus. It appears now established that the kind of damage caused by humans to the ecosystem, and especially air pollution, are aggravating factors of numerous infectious diseases, ${ }^{66}$ and this has certainly been true in the case of Covid-19. ${ }^{67}$ In other words, the pandemic is an alarm bell alerting us - more loudly than earlier with viruses like SARS, MERS, Zika and Ebola - to the great danger to human health that can result from the gradual degradation of the environment and the ongoing wounds inflicted by humans on the Planet. Suffice it to think of the bacteria nesting in the glaciers melting due to global warming; bacteria that could unleash on humans with lethal effects.

We must protect the Planet. The earth and humans do not constitute two different, juxtaposed entities. They nurture each other. Thus, it is necessary for humans to be conscious of the risks ensuing

64 Letter from Michel Houellebecq (Prix Goncourt 2010) published on France Inter site (4 May 2020): he wrote: "We will not wake up after the lockdown in a new world. It will be the same, just a bit worse". The French version of this sentence reads: "Je ne crois pas une demi-seconde à l'idée d'un monde d'après plus généreux et solidaire. Au contraire, tout restera exactement pareil, seulement en un peu plus pire".

65 Olga Tokarczuk "A New World Through My Window" The New Yorker (online ed, New York, 8 April 2020):

Melting like snow before our eyes is the paradigm of the civilisation in which we have been raised for the last two hundred years: that we are the masters of Creation, that wan do everything and that the world belongs to us. New times are coming!

Olga Tokarczuk was the Nobel Prize winner for Literature 2018.

66 N Watts and others "The Lancet Countdown: Tracking progress on health and climate change" (2017) 389 Lancet 1151.

67 L Becchetti and others Understanding the Heterogeneity of Adverse COVID-19 Outcomes: The Role of Poor Quality of Air and Lockdown Decisions (pre-print, World Health Organisation, 10 April 2020). 
from a wounded ecosystem, and thus to do all they can to prevent them. To secure a more sustainable future for humankind, we must move forward together, united as one, beyond geographical, cultural and ethnic borders. This means making peace among ourselves, referring disputes between States to settlement by an impartial arbitrator of recognised authority.

\section{$H$ The ICJ and the Transfer of Dispute Resolution between States from the Political Arena to the Field of Law}

The road leading to the substitution of the power of law to law of power is best illustrated by the transformation of jus bellum into jus contra bellum. Just as within the State the legitimate use of force is reserved to the public authorities while its use by individuals is precluded except in exceptional circumstances, similarly, in relations among States, the use of force - on the basis of the UN Charter - may only be authorised by the Security Council (as sort of a "representative" of the international community), ${ }^{68}$ and its use by States only allowed in cases of self-defence. ${ }^{69}$

Yet, this important step forward, albeit necessary, is not in itself sufficient. For a more far-reaching affirmation of the rule of law in relations between States, it would be important, it is humbly submitted, to further the role of the ICJ - the UN main judicial organ - as authoritative and independent "judge" of the behaviour of States, with exclusive jurisdiction in interpreting the Charter and in assessing the acts of the other UN organs, and in particular the decisions of the Security Council. As long as the "political" organs of the UN have a "licence", without any external control or interference, to interpret provisions of the Charter to achieve their goals, one could argue that respect for the Charter is effectively delegated to the whim - let alone arbitrariness - of political expediency of these organs. All the more so as the pronouncements of the ICJ, in requests for an advisory opinion, have only consultative value; nor is the Court afforded power of control over the legitimacy of the various acts taken by the other organs of the UN (except in very few cases). Thus, despite being bound by international law and UN organs acting, in theory, in accordance with international law, the community of States, in fact, continues to live somewhat in a "state of nature" (borrowing from Grotius), ${ }^{70}$ in a condition of relative chaos shaped in good measure by the "law of might". In other words, at the level of the UN, for instance, "self-regulation" by its organs cannot suffice in order to transform the Charter into a truly legal binding document. Instead, what is necessary is independent regulation other than the decision-making organs instituted by the charter, such as by a body like the ICJ. This is the only way, we believe, to strengthen the character of the Charter as the law (of the UN) and to entrench the rule of law in the international legal order, thereby taking the Charter to its ultimate destination.

68 Charter of the United Nations, art 42.

69 Article 51

70 Stephen C Neff (ed) Hugo Grotius on the Law of War and Peace (Cambridge University Press, Cambridge, 2012). 
Certainly, the presence at the centre of the UN system of a court endowed with exclusive jurisdiction as regards the interpretation of the Charter and the validity of the acts of the Security Council and of the General Assembly, including their observance of basic human rights, as well as jurisdiction over disputes among member States that cannot be resolved by diplomatic means, would have the effect of suggesting a strong limitation of the State sovereignty, and in particular that of the five members States that enjoy permanent, privileged representation on the Security Council. But the "law of the strongest" is precisely what underpins the Security Council. There, strategic powers are put in the hands of the most powerful States (following WWII) who are free to "play" with the interpretation of the Charter as it best suits their national interests, and who accept as sole limitation the veto power of the other permanent member States. In fact, the only thing a permanent member of the Security Council cannot do is to undermine the primary interests of the other ones.

This current situation renders the "legal order" of the UN system highly unstable. Numerous examples could be adduced here, where UN "law" remains dead letter due to the fact that its implementation remains at the mercy of States, or, more precisely, of the "calculations" of political decision-makers. In the LaGrand case (Germany v United States), ${ }^{71}$ for instance, the ICJ gave notice to the United States authorities to suspend the execution of the death sentence pronounced by the State of Arizona upon a German citizen, Karl LaGrand, after the ICJ had found a violation in his case of the right to consular assistance and, therefore, the infringement of his right of defence. ${ }^{72}$ What is interesting in this case is that the ICJ found that its order "to take all measures at its disposal to ensure that [the German national] was not executed pending the final decision in [the proceedings]" was "not a mere exhortation", but "created a legal obligation for the United States". ${ }^{73}$ However, the German national was executed at the scheduled time by the United States, in application of the municipal doctrine of "procedural default."74

Another example of the fact that States can evade their obligation to implement the decisions of the ICJ is the case Germany $v$ Italy, Judgment 2012, February $3 .{ }^{75}$ The Italian courts had found that

71 LaGrand (Germany v United States of America (Merits) [2001] ICJ Rep 466 [LaGrand Case].

72 Vienna Convention on Consular Relations 596 UNTS 261 (signed on 24 April 1963, entered into force 19 March 1967), art 36

73 LaGrand Case, above n 71, at [110].

74 See Martin Mennecke and Christian J Tams "Decisions of International Tribunals: the International Court of Justice - LaGrand Case (Germany v. United States of America)" (2002) 51 International and Comparative Law Quarterly 449.

75 Jurisdictional Immunities of the State (Germany v Italy: Greece intervening) (Judgment) [2012] ICJ Rep 99. See discussion in Alberto Costi (ed) "Immunities" in Public International Law: A New Zealand Perspective (LexisNexis NZ Ltd, Wellington, 2020) 449 at 449-451; and see also Matt McMenamin "State Immunity Before the International Court of Justice: Jurisdictional Immunities of the State (Germany v Italy)" (2013) 44 VUWLR 189. 
certain plaintiffs, victims of heinous Nazi crimes, had the right to obtain redress for damages from the German State. In response, Germany brought proceedings against Italy before the ICJ, requesting the Court to reiterate the customary norm of international law on the immunity of States from civil jurisdiction of other States for acts performed in their sovereign capacity (acta jus imperii). The ICJ ruled that despite their heinous nature, the acts performed by Nazi forces were attributable to, and thus were sovereign acts of, the State to which jurisdictional immunity applied before Italian courts. Interestingly, despite accepting the result of the judgment, the Italian Constitutional Court, two years later, ruled by its judgement $\mathrm{n} 238 / 2014$ that the immunity of States from civil jurisdiction of other States' judicial process for acts jure imperii should be deemed inapplicable in cases of war crimes and crimes against humanity because such crimes cannot be considered sovereign acts. In its view, the State immunity norm did not apply, as it would exclude the basic right of each individual to take legal action for the protection of their rights. Consequently, the Constitutional Court declared that the ICJ judgement should not be enforced in Italy.

This expression of weak and patchy compliance does not only affect the rulings of the ICJ, it also pertains to resolutions of the Security Council, at least as regards to its more powerful members. On 31 March 2019, for instance, President Trump recognised Israel's claims to the Golan Heights, declaring: "After 52 years it is time for the United State to fully recognise Israel's sovereignty over the Golan Heights". ${ }^{76}$ The fact that such a decision, in addition to being taken unilaterally by one of the permanent members of the Security Council, flatly contradicts landmark resolutions of the Security Council, both of which "censured" any attempt by Israel to "annex" that area "as null and void and without international legal effect". ${ }^{77}$ The fact that the interpretation and the application of such important instruments appears so wavering cast a shadow on the respect - alongside that of the uncertainty of the rule of law - for the purposes of the UN especially that of maintaining good international relations, in line with the principles of peace and justice.

In the same vein, In Case Concerning Avena and Other Mexican Nationals (Mexico v United States of America) (Judgment) [2004] ICJ Rep 12, some Mexican nationals were sentenced to death without, in the course of their trial, benefiting from consular assistance from their State of nationality. The United States Supreme Court, in Medellin v Texas 552 US 491 (2008), observed that:

to be binding on U.S. courts, international treaties must be self-executing or implemented by supporting laws created by Congress. The ICJ does not bind U.S. courts with its decisions, so the executive branch cannot enforce them unilaterally, nor can it enforce International treaties that are not binding.

76 Julian Borger "Trump says US will recognize Israel's sovereignty over Golan Heights" The Guardian (online ed, Manchester (UK), 21 March 2019) <www.theguardian.com>.

77 The first resolution, SC Res 242 (1967), was unanimously adopted the day after the Six Days' War; the second, resolution was SC Res 497 (1981). 
Providing the ICJ compulsory jurisdiction to settle inter-State disputes would, in some cases, preclude tensions and even possible armed conflicts. ${ }^{78}$ That said, such a competence would require two important conditions to ensure support by States: maintaining a thorough process of selection of judges; and ensuring that enforcement of its decisions does not fall foul of the veto of the permanent members of the Security Council. First, the selection of judges is currently subject to an election process. Although there is no doubt about the expertise of the members of the ICJ, maintaining a very high threshold in the selection of candidates is important, which should be organised in such a way that only candidates who, on painstaking examination of their professional qualifications and of their character, are able to guarantee great prestige, integrity and impartiality. ${ }^{79}$ Trying as much as possible to uphold a jurisdiction independent of the States and of the political organs of the UN would have, inter alia, the merit of strengthening the process, and in its own way, "international democracy".

Secondly, a current weakness of the ICJ at the moment lies in the absence of any real process of enforcement of its judgments despite the power of referring the matter to Security Council. ${ }^{80} \mathrm{With}$ no recourse to proper coercive measures, the authority of the Court - one could maintain - is destined to wither away, and its rulings to remain in consequence unimplemented. This weakness does not necessarily affect the credibility of the judicial body - the Court of Justice of the EU is there to prove it - but that of the respect for the rule of law and for certainty in international relations.

Certainly, the ICJ cannot possibly preclude insidious forms of warfare that are creeping up on us, such as wars waged using certain technologies: artificial intelligence, machine learning and bacteria. But the institution of a Court with compulsory jurisdiction at the centre of the UN system would at least demonstrate that at that point, States - which, we must always remember are governments acting on mandates from their citizens - may have learnt, finally, not to behave, in the field of international

78 As a matter of fact, the main obstacle to such a possibility is the cardinal principle of consent: no State can be subject to the jurisdiction of the Court unless it is explicitly or implicitly accepted to do so. See for example J Patrick Kelly "The International Court of Justice: Crisis and Reformation" (1987) 12 Yale J of Intl Law 342; and Mohammed Bedjaoui, former President of ICJ The Limitations on the Contribution by the International Court of Justice to the Maintenance of Peace (15 October 1996) at 7-8. Erika De Wet The International Constitutional Order (ICLQ, 2006) at 51-76 reminds us that at the end of the 1950's, the Institut de droit International was pressing States to consent to the compulsory jurisdiction of the ICJ, highlighting already then the absence of compulsory jurisdiction as one of the weaknesses of the Court.

79 Rightly stressing this point, as part of a highly meticulous analysis of the many varied proposals for reforming the ICJ, Ralitsa Nesheva "100 Years of International Justice - Time to consider a reform of the International Court of Justice" (2015) 2 IALS Student Law Review 12.

80 United Nations Charter, art 94 states that "Each Member of the United Nations undertakes to comply with the decision of the International Court of Justice in any case to which it is a party": art 94(1). Further, according to art 94(2):

if any party to a case fails to perform the obligations ... the other party may have recourse to the Security Council which may, if it deems necessary, make recommendations or decide upon measures to be taken to give effect to the judgment. 
relations, in ways which they severely forbid their citizens from behaving inside the State, and will likewise have learnt to conduct themselves in their relations with other States in the same way that they expect their citizens to act. In particular, there will no longer be a truly glaring difference between the "criminal" behaviour of the State at war, and the absolute prohibition of the use of violence that States impose on citizens within their borders.

\section{Sustainable Development through the Creation of Solidarity Blocs}

Peace among the nations and peoples of the earth constitutes a goal in itself and an instrument for achieving another aim: that of healing (as much as is possible) the wounds exacted on our Planet and avoiding the infliction of wounds on ourselves. To this first objective - protecting the Planet from humans' ravages - we must add another one: protecting humans against the Planet, and on the Planet. Sustainable development, which should be the goal, includes, alongside the safeguard of the environment, a social dimension relative to the quality of life.

It is useful to start with the second aspect. The "social State", which protects a considerable amount of the economy from the laws of the market, has slowly had to surrender to a rival principle, the free movement of capital. Following the routes of profit, capital goes where it finds the greatest return. The volatility of capital collides with the disbursements necessary to maintain social welfare. In this clash, the free movement of capital tends to prevail, eroding the social State. ${ }^{81}$

One of the first consequences concerns, in dramatic fashion, the public health system, evidenced by the brutal cuts to its earmarked funding - and consequently of healthcare services - as well as reductions in health cover and restricted access to direct care. This situation has been dramatically illustrated by Covid-19. The States with the highest ratio between the numbers of infections and of deaths (United Kingdom, France, Italy, Spain) are also the States where austerity policies have most strongly penalised the public health system in recent times. ${ }^{82}$

A second consequence, equally important, has been the gap between protection guaranteed to those performing "traditional" type jobs in stable employment, now receding, and the situation of

81 It should be remembered that the complex mechanisms of the welfare State (for instance, healthcare, social security benefits, occupational safety and health, minimum wages) have undergone a process of erosion unfolding in three phases. The first took place at the time of the so-called "fiscal crisis" of the State, in the mid-1980s. The second occurred at the collapse of the Soviet Union, when the Western democracies no longer needed to hold their own against the Communist bloc in the field of social welfare. The third was the consequence of the financial crisis that started between 2007-2008.

82 Aaron Reeves and Marina Karanikolos "Austerity and Health: The Impact in UK and Europe" (2017) 27 European Journal of Public Health 18. See also Ligia Giovannella "'Austerity' in the English National Health Service: fragmentation and commodification - examples not to follow" (2016) 32 Cadernos de Saùde Pùblica 1678. 
those in so-called "precarious employment" or with zero-hour contracts. ${ }^{83}$ The latter situation affects an ever larger proportion of the working population, and especially the young, who are excluded from the social protection system, forced into a less or entirely unprotected work limbo.

To secure, from this point of view, "sustainable" development, in other words, to maintain both development and sustainability, requires the creation of an "area" of adequate magnitude capable of optimally valuing existing productive potentialities, making it more advantageous for capital funds to remain inside the territory, thus bringing to a halt the migration of capital.

As regards to the need to protect the Planet from humans' effects, we come again to the fateful question: in what way? How to provide joint solutions to a problem, or a series of inter-related problems, often with a global, or at least regional, character in the absence of a global government able to tackle these problems? To answer this question, it is useful to follow "covert tracks", barely visible, that can already be found in the field of international law. Let us keep things in perspective.

Direct measures to protect the environment, to fight climate change, to promote sustainable development and to safeguard public health have been elaborated for some time by individual States and in international agreements. ${ }^{84} \mathrm{We}$ need to point out that now, for different reasons, these measures have undergone a marked contraction or have shown limited effectiveness in practice.

In the abstract, the most apposite realm to the protection of the environment at large would seem to be that of international agreements. However, it is difficult to uphold that the principle of sustainable development - whereby the environment must be protected to benefit not only the present generation, but also future generations - really constitutes a norm of international customary law and should thereby be immediately applicable in the legal systems of the States, notwithstanding the fact that the ICJ or at least some of its members in some decisions and advisory opinions have implied it is. ${ }^{85}$ It is at least an emerging one, we can say with a degree of confidence.

83 Zero hour contracts do not have set work hours, but require an employee to be available for a range of hours: Community Law "Zero-hour contracts and availability clauses" Community Law Manual Online <www.communitylaw.org.nz>.

84 The principle of sustainable development represents a primary commitment also of the UN: see for example Transforming our World: the 2030 Sustainable Development GA Res 70/1 (2015). Still on the theme of sustainable development, as Christian Felber Trading for Good - How Global Trade Can be Made to Serve People Not Money (Chicago University Press, Chicago, 2019) argues, respect for human rights, social justice and the environment, as well as compliance with the existing UN treaties, creates among States an area of ethical economics within which international trade flows more easily; provided, naturally, that actions in the economic field by States that pertain to this "ethical area" do not instil protectionism.

85 After Gabčikovo-Nagymaros Project (Hungary/Solvakia) (Judgment) [1997] ICJ Rep 7 [Danube Dam], the ICJ proclaimed "the environment is not an abstraction but represents the living space, the quality of life and very health of human beings, including generations unborn": at [53]; and Vernon Rive "International Environmental Law" in Alberto Costi (ed) Public International Law: A New Zealand Perspective (LexisNexis 
In practice, achievement of economic development compatible with respect for the natural environment is not within the scope of any single State separately adopting intervention measures. These measures have concerned mainly limiting polluting emissions, recycling or reusing materials, methods of waste treatment and prohibiting the use of certain products. The common characteristic of these provisions is that each time, they start from the need to protect humankind, and they are sector specific. If instead, the discussion shifts from humans to the protection of the natural environment, and still further to the protection of that particular "resource" which is the Planet as a whole, the sole state scale is visibly insufficient - we need global action on a world scale.

Discernible, therefore, is the need for a supranational public agency. The decision by sovereign States to delegate important regulatory powers to a supranational authority, thereby limiting their freedom of action, can easily be explained, at least in part, precisely by the fact that single States are not able to solely manage the problems that entail a multi-state scale. This is taken together with the fact that intergovernmental agreements are hardly credible in the absence of independent organisms that are able to monitor their correct implementation.

For sure, this process will not be completed any time soon, but it is underway gradually, under the "pressure" of necessity. This development leads to the creation of solidarity blocs or bolstering preexistent ones. Solidarity refers to those organisations that are - preferably but not necessarily regional, formed of peoples and nations bonded by relations of cultural affinity and common interests; an example of such commonality is the interest to "stay inside" the circuit of economic well-being in a way that sustains the protection and the resources of the territory, ${ }^{86}$ and the reciprocal affording of assistance. It consists of organisations capable - at least in the abstract - of giving birth to, beyond national differences, "a single great republic", as the great British 18th century historian Edward Gibbon loved to write with reference to the Europe of his times. ${ }^{87}$

NZ Ltd, Wellington, 2020) at 741. The Court itself in Pulp Mills on the River Uruguay (Argentina v Uruguay) (Judgment) [2010] ICJ Rep 14, recognised in International law for the protection of the environment at [94]:

the general obligation of States to ensure that activities within their jurisdiction and control respect the environment of others States or of areas beyond national control is now part of the corpus of International law relating to the environment.

In the same sense, The Legality of the Threat or Use of Nuclear Weapons (Advisory Opinion) [1996] ICJ Rep 241.

86 The realisation of "sustainable development", that is the pursuit of a freely competitive market economy that nevertheless also embraces the social dimension and attention to safeguarding the environment, constitutes one of the characteristic aims of the EU: see Treaty of Lisbon, above n 57, art 3 and Treaty on the Functioning of the European Union (signed 25 March 1957, entered into force 1 January 1958) [TFEU], art 11.6. See also the "conclusions" presented by the Advocate General Kokott, Case C-43/10 Nomarchiaki Aftodioikisi Aitoloakarnanias and Others v Ipourgos Perivallontos and Others ECLI:EU:C:2012:560 at 235-239.

87 It is necessary, it is worth pointing out, to look at things with "lucid realism", and thereby not to indulge in an idealistic notion of regional organisations. In his analysis of the lights and shadows of regional organisations, Laurie Nathan The Peacemaking effectiveness of Regional Organisations (LSE Development Studies 
To this should be added continuous and permanent integration among the various organisations. In this regard, a connecting network could be set up. One could think, for example, of taking the first step through the creation of a single digital gateway serving as an entry point for the live exchange of expert information and viewpoints among the decision-making organs and among the dispute resolution bodies of these various organisations. This could be followed by opening a "meeting room" or forum to foster coordination in their deliberations. This would require imagining a globalisation structured in solidarity blocs. Solidarity organisations already exist now in Europe, in Africa and in Latin America. Others could emerge. One, for example, among Australia, Canada, the United Kingdom and New Zealand, tied, as it now already is, to the United States - the "Five Eyes" - from the standpoint of security issues, but otherwise independent. We could think of another in Asia, among Japan, South Korea, Singapore and Malaysia, and again in Asia, another solidarity organisation could arise among North Korea, Vietnam and Cambodia, connected politically with China.

\section{$J$ The Dynamics of Supra-nationalism}

A supranational government, for our purposes, means shared power. This concept signifies limiting single, individualistic State authority and replacing it with joint, relations of solidarity among them, from the "disjunction" to the "conjunction" of power. At the supranational level, this "transformation" entails at first instance establishing with great precision the distinctive sphere of authority with which the central, supranational authority may operate vis-à-vis States. As an example, we could refer to a clause of "enumerated powers", along the lines of that contained in the constitution of many federal States ${ }^{88}$ or in constituent instruments of many international organisations. ${ }^{89}$ Such a framework would afford States the strongest guarantee of safeguarding their sovereignty as they would consent to the jurisdiction handed over to the supranational authority. It would also ensure a degree of certainty and stability in international relations as the enumerated powers would have - in preference to soft law - a binding character, and the supranational authority would thus be granted power to lay down minimum provisions, in those areas falling under this jurisdiction, that States could not ignore without violating their international obligations thus contracted. A useful example would be the directives adopted within the EU framework. The supranational authority would set out binding guidelines, which the recipient States would be required to implement, with free choice as to the forms and means of implementation - such as national legislation or regulation - within a prescribed time.

Despite its misgivings, the best-case study of such a supranational authority, due to the high degree of integration characterising it, is the EU, within which there coexist intergovernmental relations,

Institute, October 2010), points out that some of them turn out to be more or less far from achieving their goals - that is, to help to create a pacific regional environment and sustainable economic growth, which were the objectives of their formation.

88 As an example, United States Constitution, art I, § 8 .

89 As is the case for the distribution of competences among member States and the EU. 
supranational processes and democratic systems. The EU is also where independent control bodies and processes ensure that all concerned - States, the EU and the citizens - can evolve in a stable and certain legal and political environment. In particular, the institutional framework of the EU stands on five pillars: three of which - the European Parliament, an organ elected directly by the peoples of Europe; the Council of Ministers of the member States; and the European Council of the Heads of State and of Government - have a strictly political character; the other two, the Commission and the Court of Justice are essentially "technical" in character. What we have here is a particular form of "rational" government, where the direction of the general political and decision-making powers is in the hands of political organs, while the powers of initiation of measures and their vigilance and control are assigned to the "technical" organs. This special mode of organisation of power, that makes the EU a special case, could nevertheless be considered if, and when, in a distant future, the elaboration of a "global power" were to be undertaken to ensure: the respect of the rule of law and democracy, the interests of the States and the welfare of the nations and peoples of the world; and - at the same time - the capacity to take decisions with immediate effect at a high level of technical expertise. For the exercise of the functions with which it has been granted, the EU avails itself of a vast range of decision-making powers that include norms, standards, minimum thresholds to be met, along with goals and general and specific objectives to be pursued.

In any event, the creation of supranational authorities or the necessary empowerment of existing organisations seem to be the most efficient tools while awaiting the institution of a global government, in order to keep the peace among participating States and to develop a strong "culture of peace"; to manage - or to manage better - defined spheres of activities that entail clear consequences on the international plane; and to stem the tide of excessive power of international finance.

\section{SO MAYBE ONE DAY ...}

Our imagination and idealism can only go so far. Should it prove possible to set up a global government instituted on the basis of a federative covenant, it would mean that - on that day - the institutional structure of the UN would be complete. The Security Council would have as permanent members both States and "solidarity" organisations; and so, the United States, Russia, China, India and Iran would stand side by side with the EU, the African Union, and perhaps analogous organisations in Asia and the Pacific. A committee of experts at the highest professional level, including epidemiologists, geologists and economists would operate alongside the Security Council, and with regard to certain predetermined issues, would have to be consulted. However, unless its advice would be considered binding, the Council could disregard it. In such a way, it is hoped, "shortsighted" politics - especially the Security Council - could be adjusted by "far-sighted" science, as part of cordial relations between them.

This decision-making power could be subject to two control organs. First, the General Assembly of States, as is the case in every democratic society, would play a central role, both through the adoption, jointly with the Security Council, of decisions on common "projects" (concerning, for instance, the protection of the environment and the respect of basic human rights) and by deciding 
every year, in advance, the policy parameters within which the Council could act, by simple majority or by a two-thirds majority. ${ }^{90}$ Secondly, the ICJ, with compulsory jurisdiction, could ensure the uniform interpretation of the UN Charter and the respect of the attribution of powers among the organs of the UN, as global powers, and that of member States falling under their jurisdiction.

To achieve so much, however, humankind will have to take a giant leap forward.

90 Should a resolution of the Security Council be neither rejected nor approved by the prescribed quorum, one could envisage the intervention of a conciliatory organ along lines of the procedure as per TFEU, above $\mathrm{n} 86$, art 294. 
(2021) 52 VUWLR 